\title{
Variability in seed germination and seedling growth at the intra- and inter- provenance levels of Nothofagus glauca (Lophozonia glauca), an endemic species of Central Chile
}

\author{
Rómulo Santelices Moya ${ }^{1}$, Sergio Espinoza Meza ${ }^{1 *}$, Carlos Magni Díaz², Antonio Cabrera Ariza', \\ Sergio Donoso Calderón ${ }^{2}$ and Karen Peña-Rojas ${ }^{2}$
}

\begin{abstract}
Background: Patterns of seed germination and subsequent seedling growth of the endemic species Nothofagus glauca (Phil.) Krasser (Lophozonia glauca) (Hualo) were studied in two provenances from Mediterranean Central Chile (pre-Andean mountain range provenance and coastal range provenance). The main aim of the study was to determine differences in seed germination and seedling growth at the intra- and inter-provenance levels.

Methods: The experiment was carried out with seeds from two provenances and four to five different sites from each provenance. Seed germination tests were conducted in $10 \times 1 \mathrm{~m}$ beds in a greenhouse. Germinated seeds were sown in 140-mL containers and cultivated under nursery conditions for 8 months. After that period, growth and survival were measured.

Results: Germination, growth and survival were highly variable at the intra-provenance level. Sites from the pre-Andean mountain range provenance exhibited lower germination capacity (33.1\%) and seedling survival (76.3\%) than sites from the Coastal range provenance (40.2 and 91.3\%, respectively).

Conclusions: Provenance variability was important for seed mass and germination, and seedling survival, while intra-provenance variability was systematically higher, whatever the functional trait considered, indicating a high potential capacity of the species to adapt to climate change. This intra-provenance variability must be conserved with the use of local seed. In our case, pre-Andean sites must be established in high-elevation environments, while coastal provenances must be restricted to more lowland and coastal environments.
\end{abstract}

Keywords: Germination capacity, Hualo, Provenance, Seed size, Seedling growth

\section{Background}

Variation in seed germination reflects adaptations to site conditions (Grime et al. 1981; Nishitani and Masuzawa 1996), which strongly influence seedling growth and survival. Variability in the germination response of seeds from different provenances, populations, individuals of

\footnotetext{
* Correspondence: espinoza@ucm.cl

${ }^{1}$ Centro de Desarrollo para el Secano Interior, Facultad de Ciencias Agrarias y Forestales, Universidad Católica del Maule, Avenida San Miguel 3605, Talca, Chile

Full list of author information is available at the end of the article
}

the same population, or from different locations in the crown of the same individual tree is well known (Silvertown 1984; Martin et al. 1995; Schütz and Milberg 1997; Mamo et al. 2006). Provenances, particularly in deciduous species, from warmer climates are adapted to the longer growing season that occurs at lower elevations but suffer from early or late frosts when moved into higher elevations (Broadhurst and Boshier 2014). As a result of this polymorphic germination response, not all seeds may respond equally to a given stimulus. Indeed, population polymorphic germination responses have been found to 
be greater in unpredictable environments than in less variable ones (Meyer and Allen 1999).

South American Nothofagus species show highly variable germination behaviour, as expected for a genus that occupies a wide geographic and ecological range. For the Chilean Nothofagus species Nothofagus obliqua (Mirb.) Oerst., Nothofagus alpina (Poepp. \& Endl.) Oerst. and Nothofagus dombeyi (Mirb.) Oerst., Veblen et al. (1996) found that populations from higher latitudes tend to have lower germination capacities than those from lower latitude populations. In the case of early growth, a few studies with New Zealand Nothofagus species also indicated latitudinal differences between provenances for shoot growth (Wilcox and Ledgard 1983, Ledgard and Norton 1988). However, differences detectable in young plants were obscured by the influence of local environmental factors as the plants aged. Therefore, there is a necessity to implement field trials and, in this case, provenance trials to determine whether or not tree populations differ in terms of adaptive variation and the scale over which these differences operate.

In the present study, we investigated aspects of the seed germination and early growth of Nothofagus glauca (Phil.) Krasser (Lophozonia glauca) Heenan \& Smissen (Hualo) (Heenan and Smissen 2013). Nothofagus glauca is a temperate deciduous hardwood species, monoecious, wind pollinated and dispersed by small mammals. The species' habitat is restricted to moist sites in the coastal mountains of Chile around 100$700 \mathrm{~m}$ a.s.l. and in the Andes around 1000-1600 m a.s.l. Annual precipitation at coastal sites is in the 8441264-mm range (Santelices et al. 2013b) and is concentrated during winter and spring. Annual precipitation at the Andes sites is about $1550 \mathrm{~mm}$ and occurs in June, July and August. Nothofagus nuts are not adapted for long-distance dispersal (Donoso 1993). Female flowers produce fruits with three nuts, each with one seed. They mature from November to April, the period when seed rain occurs (Donoso and Ramírez 1994). Germination is from July to September, and seeds are desiccation sensitive so they do not form a seed bank (Donoso 1975). A characteristic feature of Nothofagus forest species is their intermittent seeding. $N$. glauca exhibits mast fruiting, as do other New Zealand Nothofagus species (Wardle 1984) and other South American species (Veblen et al. 1996). Masting usually occurs every third or fourth year when up to two million seedlings per hectare can be found (Donoso 1975).

This endemic species from the Mediterranean zone of Chile is classified as "vulnerable" by the International Union for Conservation of Nature (IUCN) (González 1998) due to the strong anthropogenic pressure of its habitat, particularly through logging and conversion to Pinus radiata D.Don plantations (Donoso 1993). In 1975,
Hualo forests covered approximately 900,000 ha (Urzúa 1975), but this area has been reduced to c.a. 175,000 ha, 66 and 34\% in the pre-Andean and coastal range, respectively (CONAF-CONAMA-BIRF 1999). Although the species produces large amounts of seed, there is limited knowledge about the seed germination of this species (e.g. Burgos et al. 2008). Also, little is known about how variable the germination response among seeds from different provenances is and whether such differences persist during the early growth phase of the germinated seedlings. Santelices et al. (1996) reported that Coastal provenances had different germination behaviour than pre-Andean provenances of this species. In the case of early growth, a few studies report the opposite (Herrera 1995, Santelices et al. 2013a), i.e. coastal and pre-Andean provenances seem to have similar growth rates at the early stages of development. This latter is consistent with the genetic structure of $N$. glauca. Coastal and Andean populations have a low genetic differentiation in neutral markers (Vergara et al. 2014).

Conservation and sustainable use of genetic resources from Nothofagus forests are dependent upon knowledge of the extent and pattern of intra-specific variation. According to Hamrick (2004) and Petit and Hampe (2006), most of the genetic variations in tree species is found within rather than among their populations; however, there is no evidence of intra-provenance differentiation for germination and seedling growth for N. glauca.

Nothofagus glauca has one of the narrowest distribution ranges of Chilean Nothofagus species (Donoso 1987). It is occurs between $34^{\circ} 80^{\prime} \mathrm{S}$ and $37^{\circ} 82^{\prime} \mathrm{S}$ (LeQuesne and Sandoval 2001), with lowland provenances restricted to moist coastal sites (Santelices et al. 2013b) and upland provenances occurring only in the Andean foot hills. These differences in habitat conditions present a basis for hypothesising that different provenances of $N$. glauca may result in different germination response and growth capacities and that most of the variation is explained by differences within provenances. The aim of the study was to determine inter- and intra-provenance variability in germination and growth of young $N$. glauca seedlings in a nursery experiment.

\section{Methods \\ Site selection}

Two provenances of N. glauca from the Maule Region in Central Chile were studied. One was from the preAndean mountain range, and the other was from the coast (Table 1 ). These provenances are relatively close geographically (maximum distance of $150 \mathrm{~km}$ ), but they were selected because they showed important differences in environmental conditions (Table 1). Four sites for the pre-Andean provenance and five sites for the coastal 
Table 1 Geographic and climatic data for provenances and sites sampled

\begin{tabular}{|c|c|c|c|c|c|c|}
\hline Provenance & Site & $\begin{array}{l}\text { UTM W } \\
(\mathrm{m})\end{array}$ & $\begin{array}{l}\text { UTM S } \\
(\mathrm{m})\end{array}$ & $\begin{array}{l}\text { Elevation } \\
\text { (m a.s.l.) }\end{array}$ & $\begin{array}{l}\text { M.A.R } \\
\left(\mathrm{mm} \text { year }^{-1}\right)\end{array}$ & $\begin{array}{l}\text { M.A.T } \\
\left({ }^{\circ} \mathrm{C}\right) \\
\end{array}$ \\
\hline \multirow[t]{4}{*}{ Pre-Andean } & Las Lomas (LO) & 320,325 & $6,100,247$ & 1590 & 1473 & 10.3 \\
\hline & Vilches (VI) & 312,209 & $6,063,144$ & 1390 & 1315 & 10.3 \\
\hline & Los Boldos (BO) & 301,134 & $6,043,585$ & 1150 & 1235 & 9.3 \\
\hline & El Melado (ME) & 318,464 & $6,033,156$ & 1200 & 2086 & 8.9 \\
\hline \multirow[t]{5}{*}{ Coastal } & Licantén (LI) & 227,317 & $6,125,186$ & 163 & 708 & 13.1 \\
\hline & Coipué (CO) & 766,281 & $6,096,054$ & 198 & 709 & 13.9 \\
\hline & Costa Azul (CA) & 731,298 & $6,081,970$ & 35 & 837 & 13.7 \\
\hline & Curanipe (CU) & 717,687 & $6,027,040$ & 35 & 837 & 13.7 \\
\hline & Tregualemu (TR) & 706,395 & $6,009,737$ & 40 & 750 & 14.1 \\
\hline
\end{tabular}

M.A.R mean annual rainfall, M.A.T mean annual temperature, UTM $W$ and UTM S Universal Transverse Mercator projection

provenance (i.e. intra-provenance level) were selected for seed collection in March 2000. The minimum distance between any two sites was approximately $30 \mathrm{~km}$, and they were separated by some type of topographic feature such as a mountain ridge, forest, city or river. A general description and location of the seed collection sites are given in Table 1 and Fig. 1.

\section{Seed sampling}

The number of sampled trees per site ranged from 6 to 12 depending on the availability of reproductively mature individuals at the time of seed collection. We collected seed from a total of 94 mother trees. To ensure that the seeds were fully mature, ripe fruit were collected during two visits to each site. Considerable effort was made to choose individuals growing under similar climatic and edaphic conditions within a site. To ensure maximum unrelatedness, the selected seed trees were $100 \mathrm{~m}$ apart from each other. Seeds were collected and then transported to the laboratory. On March 2000, the seeds were separated manually from the rest of the plant material then weighed, dried and stored in paper bags inserted in glass containers, in the dark at $4{ }^{\circ} \mathrm{C}$ for 6 months, until used in September 2000. International Seed Testing Association (ISTA) (2006) standards were followed to clean and weigh seeds. Seed mass (SM) was expressed as the average mass of

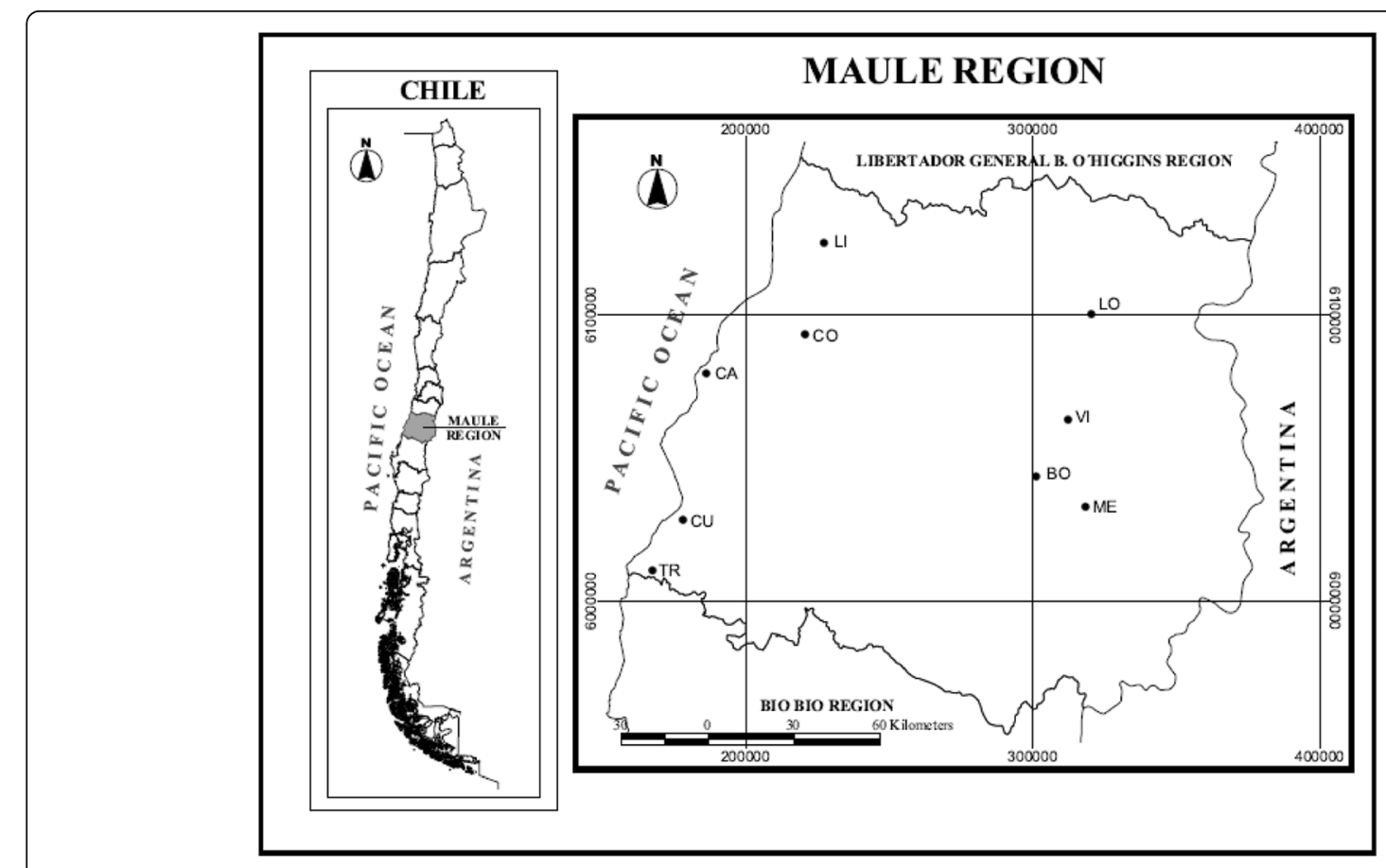

Fig. 1 Location of the Nothofagus glauca seed collection sites 
1000 seeds. For this, 100 seeds for eight replicates were weighed separately. Then the average weight of 100 seeds was calculated and multiplied by 10 (i.e. 1000 seeds weight $=100$ seeds weight $\times 10)$.

\section{Seed germination variability}

The study was conducted in a greenhouse located in the Universidad Católica del Maule, Talca, Chile (35 26' S, $71^{\circ} 37^{\prime} 13^{\prime \prime} \mathrm{W}, 131 \mathrm{~m}$ a.s.l.). Seeds were soaked in distilled water for $36 \mathrm{~h}$, and those that floated were excluded as they are considered unviable. Thirty seeds from each of 94 mother trees (i.e. a total of 2820 seeds) were sown in a saw dust and soil mixture in 10-m-long and 1-m-wide beds. A temperature of $20{ }^{\circ} \mathrm{C}$ was maintained by bottom heating (Fig. 2). Each site consisted of 6 to 12 mother trees, but seeds from individual trees were not pooled; thus, half-sibs (i.e. related individuals with only known mother; the father is different for each individual) were used in the experiment. All beds were irrigated four times a day by means of sprinkle irrigation with tap water. Germination percentage was recorded at daily intervals after the first emergence was observed. Those seeds whose cotyledons had emerged were considered as germinated. The minimum duration of a test was 30 days, and counting continued until no germination occurred for five successive days. The germination capacity (GC), expressed as the proportion of total number of germinated seeds to that of sown seeds, was determined (Bonner and Karrfalt 2008).

\section{Seedling growth and survival}

For the growth and survival experiment, the germinated seeds were set to germinate in $140-\mathrm{mL}$ containers (Termomatrices ${ }^{\oplus}$, Santiago, Chile) and cultivated in a nursery from mid-September 2000 to mid-May 2001. A mixture of $P$. radiata bark and perlite $(7: 3, v / v)$, plus the slow release fertiliser Basacote ${ }^{\circ} 9 \mathrm{M}(16 \% \mathrm{~N}, 8 \%$ $\mathrm{P}_{2} \mathrm{O}_{5}, 12 \% \mathrm{~K}_{2} \mathrm{O}, 12 \% \mathrm{SO}_{3}, 2 \% \mathrm{MgO}, 0.02 \% \mathrm{~B}, 0.05 \% \mathrm{Cu}$, $4 \% \mathrm{Fe}$ and $0.06 \% \mathrm{Mn}$ ), at a dose of $4 \mathrm{~g} \mathrm{~L}^{-1}$ of substrate, was used as the growing medium. Seedlings were protected by a $50 \%$ plastic mesh sunshade (Raschel ${ }^{\circledR}$ ) and watered to full capacity. In this period, average temperature and relative humidity were between 14 and $20{ }^{\circ} \mathrm{C}$ and 60 and $70 \%$, respectively. The experimental setup comprised two provenances, four to five sites according to the provenance and six to nine mother trees per site (Fig. 2). Nine seedlings from each mother tree were used. Eight months after sowing, total height in centimetre $(H)$, root collar diameter in millimetre $(D)$ and survival (SUR) were measured in all seedlings. Survival was measured according to a categorical scale (i.e. 1 = alive, 0 = dead).

\section{Statistical analysis}

All traits were analysed through two-way ANOVA using a nested design with two levels and a covariate. Mother plants and sites are random nested factors within provenance, provenance is a fixed factor and seed mass is the covariate, which was tested at both the between- and within-provenance levels. This was done with type-III

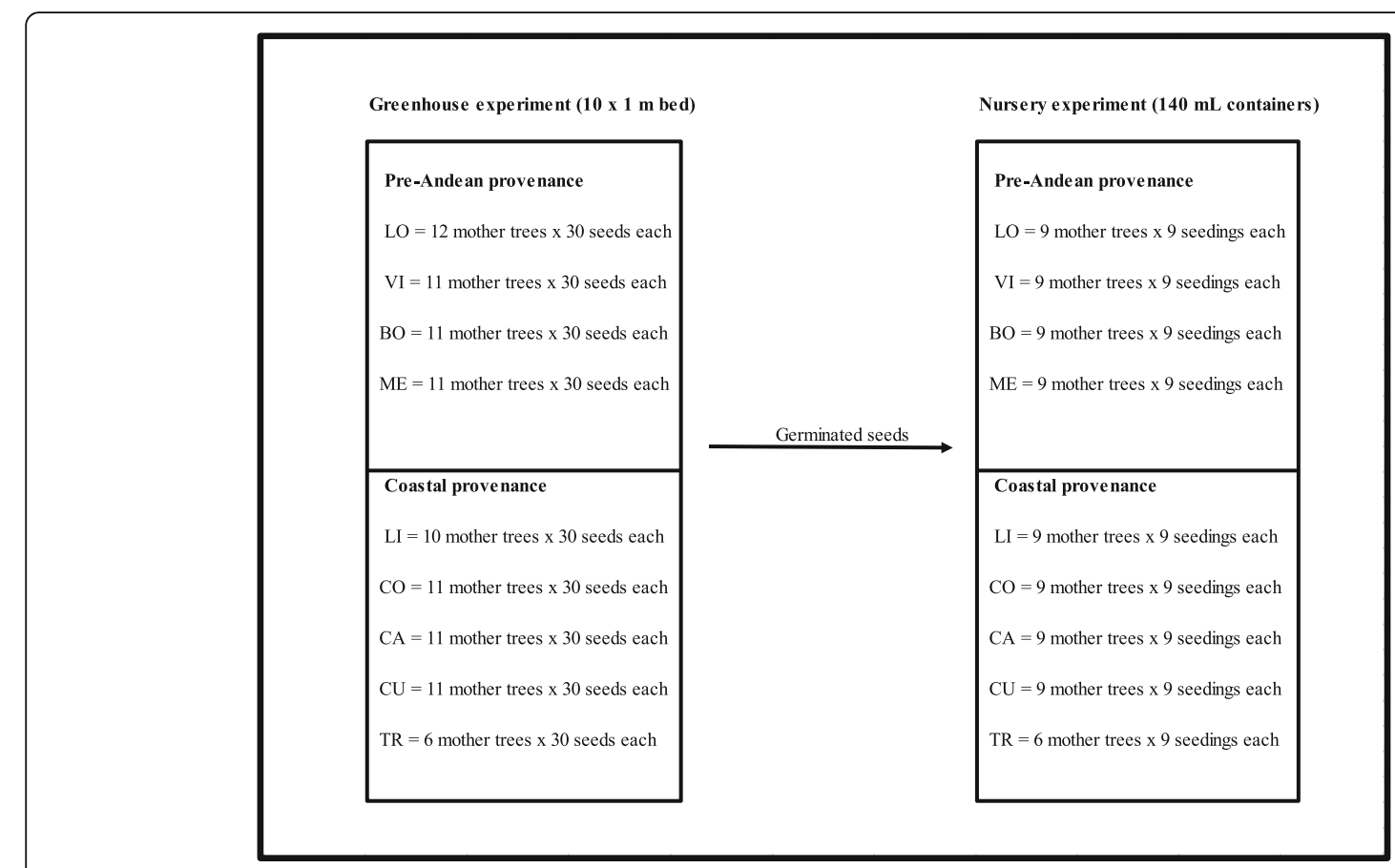

Fig. 2 Schematic diagram for germination and seedling growth experiments 
sum of squares, using SPSS software version 18 (SPSS Inc., Chicago, IL, USA). The mean values showing significant differences were compared with the Tukey test at $P \leq 0.05$. In the germination experiment, the germination capacity at the end of the germination experiment and seed mass were analysed. The results of all tests are presented as both final germination percentage and as Czabator's factor (Czabator 1962). This factor combines maximum daily average germination (called "peak value") and average daily germination at the end of the test to form one statistic called "germination value". In the growth experiment, comparisons for categorical variables (i.e. SUR) were done using a chi-square test. Associations between germination capacity with latitude and climatic variables were analysed using Pearson's correlation coefficient. Climatic data for the study area was obtained from Santibáñez and Uribe (1993).

\section{Results}

\section{Intra- and inter-provenance variability in seed germination}

Provenance and site within provenance had significant effects on most traits under consideration; however, when seed mass was analysed as a covariate, no influence in germination capacity and germination value was detected (Table 2). The overall mean germination capacity of $N$. glauca seeds under nursery conditions was $36.8 \%$, and there was variability depending on the site of origin. The mean germination capacity of seeds from the pre-Andean provenance ranged between 19 and 48\% at the El Melado and Las Lomas sites, respectively. In the coastal provenance, differences were also found with germination capacity ranging from 27 to $45 \%$ at Curanipe and Coipué sites, respectively. For the germination values, significant differences only occurred among sites and not between provenances. The germination

Table 2 Significance level of the provenance, the intra-provenance and the covariate effects (seed mass) on the variance of germination, growth and survival traits measured in Nothofagus glauca

\begin{tabular}{llllllll}
\hline Source of variation & df & GC & GV & SM & D & $H$ & SUR \\
\hline Covariate & & & & & & & \\
$\quad$ Seed mass & 1 & 0.390 & 0.662 & - & 0.497 & 0.248 & 0.762 \\
Main effect & & & & & & & \\
$\quad$ Provenance & 1 & 0.041 & 0.979 & 0.016 & 0.758 & 0.879 & 0.002 \\
$\quad$ Site (provenance) & 7 & 0.039 & 0.000 & 0.001 & 0.006 & 0.017 & 0.000 \\
$\quad$ Error & 84 & & & & & & \\
\hline
\end{tabular}

Statistically significant values $(P<0.05)$ are in italics. $P$ significance levels after Tukey's test. In the case of SUR, the $P$ value corresponds to the chi ${ }^{2}$ test GC germination capacity (\%), GV germination value (\%), $S M$ mean seed mass (1000 seeds) (g), D root collar diameter (mm), $H$ height $(\mathrm{cm})$, SUR survival $(\%)$ $d f$ degrees of freedom value ranged from $0.15 \%$ for seeds from the El Melado site to $2.78 \%$ for the Las Lomas site. Seed mass was different in both provenances and sites within provenances (Table 3). The pre-Andean provenance had lighter seeds than the coastal provenance. There was a positive, but low, significant correlation between GC with elevation $\left(R^{2}=0.09, P=0.00\right)$, temperature $\left(R^{2}=0.02, P=0.01\right)$ and precipitation $\left(R^{2}=0.08, P=0.04\right)$ in pre-Andean sites, while in coastal sites, no relationships between $\mathrm{GC}$ and these climatic variables were found $\left(R^{2}=0.02\right.$, $P=0.29 ; R^{2}=0.00, P=0.97 ;$ and $R^{2}=0.03, P=0.23$ for altitude, temperature and precipitation, respectively).

\section{Intra- and inter-provenance variability in seedling growth and survival}

Provenance had no significant effects on the growth of the $N$. glauca seedlings in terms of $D$ and $H$, but there were differences in survival (Table 2). For all the traits evaluated, however, there were significant intraprovenance effects (Table 2). The individuals from the Licantén site produced the largest seedlings in the nursery. Seedling survival (to age 8 months) was similar for most sites (i.e. mean of 92\%) with the exception of the seedlings from site El Melado, which had the lowest survival rate (Table 3 ).

\section{Discussion}

Germination differences between provenances and among sites

The germination requirements of a species are traits adapted to the site where the species lives (Meyer et al. 1995; Grime et al. 1981; Nishitani and Masuzawa 1996). Furthermore, seeds from different areas of a species' range often show variability in germination. Intrapopulation variability in germination is also a common occurrence in forest trees (Baskin and Baskin 1973; Hardin 1984; Martin et al. 1995), as a result of genetic factors (Van der Vegte 1978) and climate variability during seed ripening (Meyer and Allen 1999). In the present study, the germination capacity was highly variable between the two provenances studied and among sites within these provenances, ranging from 19 to $48 \%$. This result corroborates the known high variability in seed germination of the Nothofagus genus. In Chilean Nothofagus species, germination requirements have been investigated previously for $N$. obliqua, $N$. alpina and $N$. dombeyi. For these three species, the germination capacity for different stratification treatments ranges from $10 \%$ in $N$. dombeyi from coastal populations to $80 \%$ in $N$. alpina from Andean populations (Veblen et al. 1996). These data support the range of germination (19 to $48 \%$ ) observed in the current study, and that site where seed was collected strongly influenced germination response (Roach and Wulff 1987; 


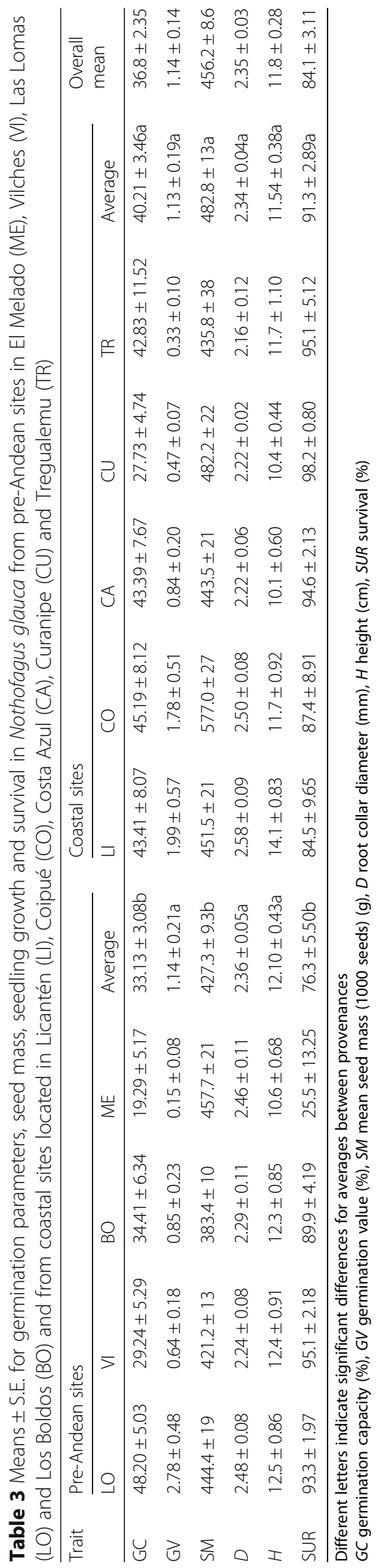


Baskin and Baskin 2014). Our results indicated that intra-provenance effects other than seed mass affected seed germination.

Differences in seed germination are also observed in seeds from different mother plants of the same population. At the seed stage, a large proportion of the variation is under maternal control which supports the contention that the genotype of the individuals also has an important influence on seed germination. Germination characteristics are also affected by conditions experienced by mother plants in the previous generation (Roach and Wulff 1987; Baskin and Baskin 2014). These mother effects can cause large variation within a region or even within a population (Baskin and Baskin 1973; Fenner 1991). In our study, the observed differences in germination capacity of $N$. glauca could be attributed to maternal effects, which are common for traits such as seed size and germination and can affect early seedling growth. On the other hand, although the Universidad Católica nursery was located in the 100-150-m range, the lower germination percentage of the pre-Andean provenance than the Coastal provenance cannot be attributed to nursery carryover effects because nursery effects may not become evident until the planted material is a third to a half of final rotation age (Campbell and Sorensen 1984). Also, seed production is variable and good mast seasons seem to occur every 2 years in Nothofagus species (Marchelli and Gallo 1999), but the results of the present study are restricted to just one season, which highlights the need for multi-year field experiments. In the case of $N$. glauca, a multiplegeneration study is also required that uses seeds from different years due to the variable masting/fruiting nature of this species.

Germination is also influenced by the elevation at which seed is collected (Holm 1994). According to Donoso (1979), marginal climates for seed development at higher elevation can lead to incomplete seed maturation, which is sometimes hard to detect visually in the seed but can be revealed during germination and subsequent seedling development (Edwards 1980). In the present study, the pre-Andean provenance had a significantly lower average germination capacity (33.1\%) than the coastal provenance (40.2\%), which could indicate that germination is related to the different elevational distribution of the two provenances. Santelices et al. (2009) found a high germination capacity (i.e. 79\%) for Nothofagus alessandrii Espinosa from the coastal provenances of the species. Unfortunately, we found low correlations between either elevation or climatic variables with germination capacity. It may be possible that the increase in precipitation and decrease in temperature with increasing elevation affected germination capacity of pre-Andean sites; however, this must be tested with more precise climatic data than that available in the current study. In the case of Nothofagus menziesii (Hook. f.) (Oerst), the total number of seeds, the number of mature seeds and seed quality decreased with an increase in elevation (Manson 1974). The elevation of the pre-Andean provenance ranges from 1100 to $1600 \mathrm{~m}$, while the range of the coastal provenance is lower than $200 \mathrm{~m}$. We also suspect that the lower germination capacity in the preAndean provenance sites (e.g. El Melado) is related to high precipitation and low temperature. However, Mariko et al. (1993) reported that the seeds of Reynoutria japonica from higher elevations (above $1500 \mathrm{~m}$ ) showed significantly higher germination and germination rate than those from the lower elevations (below $1400 \mathrm{~m}$ ), which supports the contention that germination capacity also depends on the species.

No correlation was found between seed mass and germination capacity, either for provenances or sites within provenances. In the Coipue site, from the coastal provenance, the heavier seeds showed the highest germination capacity (45\%), while the lighter seeds from the El Boldo site had a GC of 34\%. Despite no relationship between seedling survival and seed mass being found, it seems that the rule larger seeds $=$ highest germination rate does hold for N. glauca.

\section{Survival and growth differences between provenances and sites}

We found elevation-related climate differences (Table 1) between provenances that were consistent with previous studies, which suggested that seedling survival decreases with elevation (Wardle 1984). However, there was some weakening of provenance differentiation in $D$ and $H$, and these differences were attributed to intra-provenance variations only. Similar results were found by Santelices et al. (2013a) and Herrera (1995), i.e. young N. glauca seedlings from coastal and pre-Andean provenances have similar early growth rates. This means that genetic differences among maternal plants could explain most of the variation observed. Maternal effects also influence the early seedling stage of a genotype (Roach and Wulff 1987). As with germination, the low mean height from the El Melado site seems to be related to the high precipitation and low temperature of this site. In the case of survival, a better seedling survival and growth from the larger seeds could be expected, due to the greater amounts of nutritive substances they have (Harper 1977). However, no relationship was found between survival and seed mass as a covariate despite statistical differences being found for seed mass at the provenance and intra-provenance levels. This was probably because of the large-sized seed of $N$. glauca compared to other species, which can have tiny seeds with very little reserves. Also, the superior growth and survival of 
seedlings from larger seeds are more evident in nutrientimpoverished soil (Milberg and Lamont 1997). Fertiliser was applied at a rate equivalent to $0.64 \mathrm{~kg} \mathrm{~m}^{-3}$ of $\mathrm{N}$, which appeared to be sufficient for $N$. glauca seedling growth and survival. At the stand level, there would probably be some trade-offs for larger seeds, i.e. they are thought to have a superior chance of establishing as seedlings, but they are also more nutritious so are more likely to be eaten by predators. As with germination capacity and height, the lower survival observed in the preAndean provenance site El Melado could be related to the high precipitation and low temperature of this site.

In Chile, there is insufficient knowledge about variation within and among provenances of $N$. glauca. The current study added valuable information by demonstrating considerable intra-provenance variation in container-grown seedlings of this species at age 8 months housed in a nursery. However, it is unclear how these results relate to estimates of the growth capacity of mature trees in the field. Variability studies are a prerequisite to planning effective germplasm collection strategies for forest restoration and species conservation purposes (Eriksson 2014). The present study involved nine sites in two provenances and a total of 94 mother trees, which is sufficient to represent the genetic diversity of a windpollinated species (Jalonen et al. 2014). The intraprovenance variation observed suggests that admixtures from different provenances should not be used (Breed et al. 2013), when sourcing seeds for restoration. Instead, more strict conditions should be imposed to ensure local provenances are used. Allelic richness due to intraprovenance variation must be maintained as trees possesses high levels of genetic diversity that allow them to adapt rapidly to local conditions (Petit and Hampe 2006).

Results from this study give an indication of germination and seedling characteristics of young N. glauca plants grown in a controlled environment study. However, genetic differences detectable in young plants are obscured by the influence of local environmental factors as the plants mature. Therefore, field studies will be necessary to resolve the adaptive effects of the field phenotypes associated with the observed variations in germination, survival and growth traits reported here. Also, non-local genotypes may suffer from maladaptation to the local environment resulting in a lower fitness (Vander Mijnsbrugge et al. 2010), so reciprocal transplant experiments (RTEs) are needed to test how the species would respond to changing climates.

\section{Conclusions}

Most of the provenance and intra-provenance variation in germination capacity, growth and seedling survival of $N$. glauca is explained by the intra-provenance variability associated with mother effects other than seed mass or site conditions. These results indicate plasticity within the species and the potential capacity to adapt to climate change. We advocate that this high intra-provenance variation must be adequately managed. Pre-Andean seedlings must be established in high-elevation environments, while coastal provenances must be restricted to more lowland and coastal environments. These results, although recorded for nursery seedlings, emphasise the importance of field trials. The use of locally adapted seeds in large-scale plantations will minimise the risk of planting maladapted trees and will avoid indiscriminate mixing of provenances from different ecological regions.

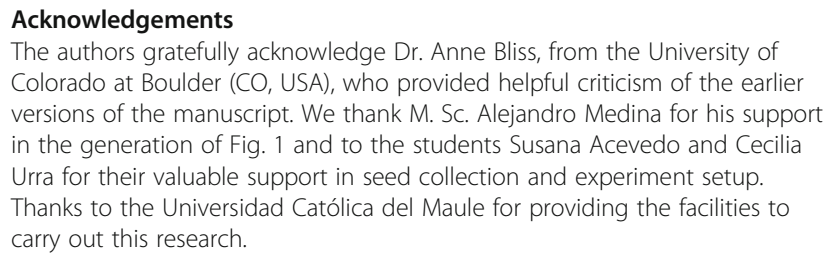

Authors' contributions

RS conceived the study, organised the sampling of seed collection and reviewed the final manuscript; SE analysed the data and wrote both the earlier draft and the final version of the manuscript; CM contributed ideas and commented on the methodology in the final draft of the manuscript; and SD, KP and AC commented on an early draft of the manuscript. All authors read and approved the final manuscript.

\section{Competing interests}

The authors declare that they have no competing interests.

\section{Publisher's Note}

Springer Nature remains neutral with regard to jurisdictional claims in published maps and institutional affiliations.

\section{Author details}

${ }^{1}$ Centro de Desarrollo para el Secano Interior, Facultad de Ciencias Agrarias y Forestales, Universidad Católica del Maule, Avenida San Miguel 3605, Talca,

Chile. ${ }^{2}$ Departamento de Silvicultura y Conservación de la Naturaleza, Facultad de Ciencias Forestales y de la Conservación de la Naturaleza, Universidad de Chile, Avenida Santa Rosa 11365, La Pintana, Santiago, Chile.

Received: 2 August 2016 Accepted: 15 March 2017

Published online: 09 May 2017

\section{References}

Baskin, J. M., \& Baskin, C. C. (1973). Plant population differences in dormancy and germination characteristics of seeds: heredity or environment? American Midland Naturalist, 90, 493-498.

Baskin, C. C., \& Baskin, J. M. (2014). Seeds ecology, biogeography, and evolution of dormancy and germination. San Diego: Academic.

Bonner, F. T., \& Karrfalt, R. P. (2008). The woody plant seed manual. Washington, DC: U.S. Department of Agriculture, Forest Service.

Breed, M. F., Stead, M. G., Ottewell, K. M., Gardner, M. G., \& Lowe, A. J. (2013). Which provenance and where? Seed sourcing strategies for revegetation in a changing environment. Conservation Genetics, 14, 1-10.

Broadhurst, L., \& Boshier, D. (2014). Seed provenance for restoration and management: conserving evolutionary potential and utility. In M. Bozzano, R. Jalonen, E. Thomas, D. Boshier, L. Gallo, C. Stepehn, S. Bordács, P. Smith, \& J. Loo (Eds.), Genetic considerations in ecosystem restoration using native tree species (pp. 27-38). Rome: Food and Agriculture Organization of the United Nations.

Burgos, A., Grez, A. A., \& Bustamante, R. O. (2008). Seed production, pre-dispersal seed predation and germination of Nothofagus glauca (Nothofagaceae) in a temperate fragmented forest in Chile. Forest Ecology and Management, 255, 1226-1233. 
Campbell, R. K., \& Sorensen, F. C. (1984). Genetic implications of nursery practices. In M. L. Duryea \& T. D. Landis (Eds.), Forest Nursery Manual: Production of Bareroot Seedlings (pp. 183-191). The Hague: Martinus Nijhoff/Dr W. Junk Publishers.

CONAF-CONAMA-BIRF. (1999). Catastro y Evaluación de Recursos Vegetacionales Nativos de Chile. Informe Regional VII Región. Proyecto CONAF-CONAMA-BIRF.

Czabator, F. J. (1962). Germination value: an index combining speed and completeness of pine seed germination. Forest Science, 8, 386-396.

Donoso, C. (1975). Aspectos de la fenología y germinación de las especies de Nothofagus de la zona mesomórfica. Boletín Técnico No. 34. Santiago: Facultad de Ciencias Forestales, Universidad de Chile.

Donoso, C. (1979). Genecological differentiation in Nothofagus obliqua (Mirb.) Oerst, in Chile. Forest Ecology and Management, 2, 53-66.

Donoso, C. (1987). Variacion natural en especies de Nothofagus en Chile. Bosque, 8, 85-97.

Donoso, C. (1993). Bosques templados de Chile y Argentina. Variación, estructura y dinámica. Santiago: Editorial Universitaria.

Donoso, C., \& Ramírez, G. C. (1994). Arbustos nativos de Chile: guía de reconocimiento. Valdivia: Ediciones Marisa Cuneo.

Edwards, D. G. W. (1980). Maturity and quality of tree seeds-a state-of-the-art review. Seed Science and Technology, 8, 625-657.

Eriksson, G. (2014). Collection of propagation material in the absence of genetic knowledge. In M. Bozzano, R. Jalonen, E. Thomas, D. Boshier, L. Gallo, S. Cavers, S. Bordács, P. Smith, \& J. Loo (Eds.), Genetic considerations in ecosystem restoration using native tree species. State of the World's Forest Genetic Resources (Thematic Study, pp. 79-84). Rome: FAO and Bioversity International.

Fenner, M. (1991). The effects of the parent environment on seed germinability. Seed Science Research, 1, 75-84.

González, M. (1998). Nothofagus glauca. The IUCN red list of threatened species. Version 2016.3. www.iucnredlist.org. Accessed 20 Mar 2017.

Grime, J. P., Mason, G., Curtis, A. V., Rodman, J., Band, S. R., Mowforth, M. A. G., Neal, A. M., \& Shaw, S. (1981). A comparative study of germination characteristics in a local flora. Journal of Ecology, 69, 1017-1059.

Hamrick, J. L. (2004). Response of forest trees to global environmental changes. Forest Ecology and Management, 197, 323-335.

Hardin, E. D. (1984). Variation in seed weight, number per capsule and germination in Populus deltoides Bartr. trees in southeastern Ohio. Journal of Appled Ecology, 112, 29-34.

Harper, J. L. (1977). Population biology of plants. London: Academic.

Heenan, P. B., \& Smissen, R. D. (2013). Revised circumscription of Nothofagus and recognition of the segregate genera Fuscospora, Lophozonia, and Trisyngyne (Nothofagaceae). Phytotaxa, 146, 1-31.

Herrera, L. (1995). Cultivo en vivero del Hualo [Nothofagus Glauca Phil. Kraser] bajo distintos grados de luminosidad y espaciamiento. Tesis Técnico Forestal, Universidad Católica del Maule, Chile.

Holm, S. O. (1994). Reproductive patterns of Betula pendula and B. pubescens coll. along a regional altitudinal gradient in northern Sweden. Ecography, 17, 60-72.

ISTA. (2006). International rules for seed testing. Edition 2006. Bassersdorf: International Seed Testing Association (ISTA).

Jalonen, R., Thomas, E., Cavers, S., Bozzano, M., Boshier, D., Bordács, S., Gallo, L., Smith P., \& Loo, J. (2014). Analysis of genetic considerations in restoration methods. In M. Bozzano, R. Jalonen, E. Thomas, D. Boshier, L. Gallo, S. Cavers, S. Bordács, P. Smith, \& J. Loo (Eds.), Genetic considerations in ecosystem restoration using native tree species. State of the World's Forest Genetic Resources (Thematic Study, pp. 245-273). Rome: FAO and Bioversity International.

Ledgard, N. J., \& Norton, D. A. (1988). Shoot growth in 2-3 year old Nothofagus seedlings. New Zealand Journal of Ecology, 11, 105-108.

Le-Quesne, C., \& Sandoval, L. (2001). Extensión del límite sur para Nothofagus glauca (Phil.) Krasser. Gayana Botánica, 58, 139-142.

Mamo, N., Mihretu, M., Fekadu, M., Tigabu, M., \& Teketay, D. (2006). Variation in seed and germination characteristics among Juniperus procera populations in Ethiopia. Forest Ecology and Management, 224, 320-327.

Manson, B. R. (1974). The life history of silver beech (Nothofagus menziesii). Proceedings of the New Zealand Ecological Society, 21, 27-31.

Marchelli, P., \& Gallo, L. A. (1999). Annual and geographic variation in seed traits of Argentinean populations of southern beech Nothofagus nervosa (Phil.) Dim. et Mil. Forest Ecology and Management, 121, 239-250.

Mariko, S., Koizumi, H., Suzuki, J., \& Furukawa, A. (1993). Altitudinal variations in germination and growth responses of Reynoutria japonica populations on Mt. Fuji to a controlled thermal environment. Ecological Research, 8, 27-34.
Martin, A., Grzeskowiak, V., \& Puech, S. (1995). Germination variability in three species in disturbed Mediterranean environments. Acta Oecologica, 16, 479-490.

Meyer, S. E., \& Allen, P. S. (1999). Ecological genetics of seed germination regulation in Bromus tectorum L. I. Phenotypic variance among and within populations. Oecologia, 120, 27-34.

Meyer, S. E., Kitchen, S. G., \& Carlson, S. L. (1995). Seed germination timing patterns in intermountain Penstemon (Scrophulariaceae). American Journal of Botany, 82, 377-389.

Milberg, P., \& Lamont, B. B. (1997). Seed/cotyledon size and nutrient content play a major role in early performance of species on nutrient-poor soil. New Phytologist, 137, 665-672.

Nishitani, S., \& Masuzawa, T. (1996). Germination characteristics of two species of Polygonum in relation to their altitudinal distribution on Mt. Fuji, Japan. Arctic and Alpine Research, 28, 104-110.

Petit, R. M., \& Hampe, A. (2006). Some evolutionary consequences of being a tree. Annual Review of Ecology, Evolution, and Systematics, 37, 187-214.

Roach, D. A., \& Wulff, R. D. (1987). Maternal effects in plants. Annual Review of Ecology and Systematics, 18, 209-235.

Santelices, R., Riquelme, M., \& Rojas, F. (1996). Aspectos sobre la semilla y germinación de Nothofagus glauca (Phil.) Krasser de dos procedencias de la VII Región. Ciencia e Investigación Forestal, 10, 297-305.

Santelices, R., Navarro Cerrillo, R., \& Drake, F. (2009). Caracterización del material forestal de reproducción de cinco procedencias de Nothofagus alessandrii Espinosa, una especie en peligro de extinción. Interciencia, 34, 113-120.

Santelices, R., Espinoza, S., Cabrera, A., Peña-Rojas, K., \& Donoso, S. (2013). Effect of shading and fertilisation on the development of container-grown Nothofagus glauca seedlings, a threatened species from central Chile. Southern Forests, 75, 1-4.

Santelices, R., Donoso, C., \& Cabello, A. (2013). Nothofagus glauca (Phil.) Krasser Hualo, Roble maulino, Roble colorado (Maule). Familia: Nothofagaceae. In C. Donoso (Ed.), Las Especies Arbóreas de los Bosques Templados de Chile y Argentina. Autoecología (pp. 433-442). Valdivia: Marisa Cuneo Ediciones.

Santibáñez, F., \& Uribe, J. (1993). Atlas agroclimático de Chile, regiones VI, VII, VIII y IX. Chile: Universidad de Chile.

Schütz, W., \& Milberg, P. (1997). Seed dormancy in Carex canescens: regional differences and ecological consequences. Oikos, 78, 420-428.

Silvertown, J. W. (1984). Phenotypic variety in seed germination behavior: the ontogeny and evolution of somatic polymorphism in seeds. The American Naturalist, 124, 1-16.

Urzúa, A. (1975). Cambio de estructura en el bosque de Nothofagus glauca (Phil.) Krasser. Tesis Ingeniería Forestal, Universidad de Chile, Chile.

Van der Vegte, F. W. (1978). Population differentiation and germination ecology in Stellaria media (L.) Vill. Oecologia, 37, 231-245.

Vander Mijnsbrugge, K., Bischoff, A., \& Smith, B. (2010). A question of origin: where and how to collect seed for ecological restoration. Basic and Applied Ecology, 11, 300-311.

Veblen, T. T., Read, J., \& Hill, R. S. (1996). The ecology and biogeography of Nothofagus forests. New Haven: Yale University Press.

Vergara, R., Gitzendanner, M. A., Soltis, D. E., \& Soltis, P. S. (2014). Population genetic structure, genetic diversity, and natural history of the South American species of Nothofagus subgenus Lophozonia (Nothofagaceae) inferred from nuclear microsatellite data. Ecology and Evolution, 4, 2450-2471.

Wardle, J. A. (1984). The New Zealand beeches: ecology, utilisation and management. Christchurch, New Zealand Forest Service.

Wilcox, M. D., \& Ledgard, N. J. (1983). Provenance variation in the New Zealand species of Nothofagus. New Zealand Journal of Ecology, 6, 19-31. 